\title{
Research on Cross-border E-commerce Talent Training for Regional Economic Development in Hainan Province
}

\author{
Qiang Wu \\ Haikou College of Economics, Haikou Hainan, 571127, China
}

Keywords: Hainan Province, Cross-border e-commerce, Talent training, Regional economic development

\begin{abstract}
The Belt \& Road" in Hainan Province serves as the main research background in this paper. Based on the actual demand of Hainan Province for cross-border e-commerce talents, this paper mainly expounds talent training in J college in Hainan Province, proposes the brand-new mode for cross-border e-commerce talent training by combining the detailed situations in order to better adapt to the development trend of regional economic development, hoping to provide some suggestions.
\end{abstract}

\section{Importance of Cross-Border E-Commerce Training in Regional Economic Development}

General Ssecretary Xi Jinping proposed the strategic conception of "New Silk Road Economic Belt" and "21 $1^{\text {st }}$-Century Maritime Silk Road" in 2013. In "the National People's Congress and the Chinese Political Consultative Conference" in 2015, Li Keqiang explicitly indicated to further drive transition of processing trade and achieve synchronous development of comprehensive service platform of foreign trade and marketing purchase so as to achieve effective expansion of comprehensive experimental unit for cross-border e-commerce. Hainan Province plays a crucial role in "the Belt \& Road" strategy. Hence, Hainan Province also actively blends in "the Belt \& Road" and specifies the important role of cross-border e-commerce in economic and social development of Hainan Province ${ }^{[1]}$. When the strategy is confirmed, the importance of cross-border e-commerce in regional economic development is also interpreted in detail. In particular, cross-border e-commerce talents have become an indispensable part of regional economy talent strategy.

The major goal of cross-border e-commerce talent training is to continuously provide high-level applied talents for economic construction and social development of Hainan. This is also a human resource investment with long-term benefits, and has a close connection with regional economic development. All-round cultivation of cross-border e-commerce talents can provide social services for regional economic development, especially for training service and technological innovation service of enterprises and public institutions.

It is necessary to note that cross-border e-commerce talent training should regard the market a the important basis, always stick to employment orientation and carry out the further study for the development law of regional economy and cross-border e-commerce talent demand. In Hainan Province, cross-border e-commerce is in the pilot stage, so the demand for professional talents will continue to rise. On this basis, it is necessary to cultivate cross-border e-commerce talents suitable for local development demand. The traditional education mode is very difficult to meet market demand, so the research on talent training mode must be conducted from the perspective of development strategy.

\section{Current Situation of Cross-Border E-Commerce Talent Training of $\mathbf{J}$ College in Hainan}

Cross-border e-commerce talents refer to the professional talents who work on marketing, human resource, e-commerce, international trade and customs clearance in cross-border electronic transaction. In current stage, J College has set up numerous professional courses such as computer networks, international trade, communication engineering, e-commerce and business English. 
E-commerce is a new major in the college. International trade major has a long history in the college, and its teaching team has developed to the provincial-level teaching team. Besides, senior executives of relevant units such as translation, customs, foreign trade corporation and freight forwarding are employed as the teachers for business English major. Hence, the zero-distance teaching mechanism with the employment market has formed ${ }^{[2]}$. Computer science and technology major of J College is also rated as a provincial-level characteristic major. Most majors of the college have formed relatively mature and sound talent training schemes in the long-term construction and development. Moreover, strong major advantages are provided in the aspects of international trade, computer network communication, business negotiation and cross-cultural communication. In particular, the achievements in the aspects of teaching team building, practice, employment and course construction are outstanding. In the practice process, each major of $\mathrm{J}$ College pays excessive attention to self-building, and fails to overall measure and consider ability demand of cross-border e-commerce talents. Cross-border e-commerce is not the random integration of existing technology and business knowledge. Its compound property and cross-border property are very obvious. It is required to deeply understand the operation of cross-border transaction system on the basis of owning strong professional knowledge. So, the workers must own multi-aspect knowledge and abilities.

\section{Construction of cross-border e-commerce talent training mode for $\mathbf{J}$ College in Hainan Province}

Based on the comprehensive consideration of ability demand of cross-border e-commerce talents, the basic mode of cross-border e-commerce talent training is proposed on the basis of cross-major comprehensive practice. In the practice process, the resources of each relevant major are effectively integrated, and the practical teaching platform of cross-border e-commerce forms. On this basis, the students of relevant majors deeply understand the operation of cross-border e-commerce transaction to further enhance their comprehensive ability whole grasping their own majors.

\subsection{To Actively Construct an Interdisciplinary Practical Teaching Platform}

In the process of constructing the interdisciplinary practical teaching platform, it is required to deeply develop software system. In the practical application process, the teacher should be responsible for management and simulating the transaction activity through cooperation so as to adapt to multi-major study and practice. Cross-border electronic transaction aims to make the enterprises with different forms achieve the effective connection in business contact. Cross-border e-commerce practical teaching platform extracts typical features of organizations with different forms to construct the virtual environment for cross-border e-commerce transaction ${ }^{[3]}$. In this way, students can take transaction content, management process and bolls as the important reference basis and complete emulation trade and business operation task according to the business rules through virtual business environment, market environment, public service environment and government environment.

The virtual commercial community environment developed by X Company - VBSE cross-major comprehensive practical teaching platform enhances teaching quality and effect in the application process. Thus, J College should form the cooperative relationship with $\mathrm{X}$ Company during constructing the cross-major practical teaching platform, while X Company develops the software system to reach the goal of platform construction. However, software development requires lots of cost, which needs to be solved.

\subsection{To Rationally Set Teaching Courses}

In the process of setting up cross-border e-commerce courses, the courses must adapt to talent training objective. Thus, the confirmation of talent training objective must be perfectly connected with regional economy of Hainan, and the actual demand for talents should be investigated. Since cross-major teaching will involve numerous majors, it is necessary to specify the talent training objective at different levels, generally including three levels: overall objective, major objective and 
practical teaching objective. The setting of overall objective shall make sure the talents can serve for regional economic development, and own strong comprehensive abilities which should adapt to the abilities required by cross-border e-commerce transaction. Meanwhile, they should own innovation ability, entrepreneurial ability and decision-making ability. In terms of sub-goal setting, the overall objective shall serve as the core, and sub-goal setting should be determined by combining talent training schemes for different majors. For practical teaching objective, the sub-goal of majors should serve as the core and be finally confirmed by combining features of different practice courses.

It is necessary to note that, the courses should consist of numerous knowledge points of cross-border e-commerce transaction, and the knowledge points should be the knowledge units which can be taught independently. Usually, the knowledge points mainly include theoretical knowledge and software operation knowledge. On this basis, students can understand software operation and professional knowledge [4]. In the practice process, cross-major practical teaching platform does not regard a major as the core, but it is a training for cross-border e-commerce transaction, posts and enterprises. So, during setting up relevant courses, it is required to organically integrate existing professional courses of $\mathrm{J}$ College and stress the importance of occupational post ability and comprehensive quality training.

\subsection{To Flexibly Design Teaching Process}

For the teaching process, it is required to complete design of the specific process by taking transaction process as the main objective. Meanwhile, it is necessary to utilize project teaching method, rationally decompose professional knowledge and form several tasks, offer necessary help for students and make them able to deeply understand professional knowledge in practice. During implementing practical teaching, it is required to strictly follow the basic processes of perceptual practice, course training, comprehensive training and cross-major comprehensive training. In the whole process, students should guarantee to make correct decisions, complete the tasks of different management posts and finally achieve practical teaching objectives at three different levels while experiencing the environment.

\subsection{To Actively Construct Scoring Mechanism}

During evaluating the learning effect, the rationality of scoring mechanism is very critical. So, the scoring mechanism should be made by comprehensively considering each teaching link and post. In the practical evaluation process, students' practice performance should be assessed fairly through multiple aspects such as pre-posttest, transaction effect, performance, practice report, communication and cooperation.

\subsection{To Strictly Require Teaching Team Building}

In terms of cross-border e-commerce talent training mode construction, the function of teaching team cannot be ignored. Thus, in the practice process, strict requirements should be proposed for teaching team. Based on mastering business English skills and international trade operation, students also should accumulate rich cross-border e-commerce operation experience and e-commerce technology. In such case, J College construct parallel teaching team of full-time and part-time teachers on the basis of university-enterprise cooperation.

Besides, famous experts of e-commerce association and foreign trade enterprise should be employed to let them undertake the responsibility of major leaders, organize and hold lectures and training activities regularly and set forth industrial development trend in detail so as to ensure overall expansion of major view and international view of teachers and students and make sure enterprise talent demand information is exchanged in time. Meanwhile, professional teachers should rationally arrange time, organize the discussion on theoretical knowledge per week, and enter the enterprises for practical activities in batches so as to improve personal knowledge system, enhance practical ability and ensure continuous promotion of teaching level. On this basis, technical personnel and management personnel in enterprises should be employed as part-time teachers to enhance guidance of students' practical skills and management ability. Based on rational application of the above 
measures, it is required to make sure professional talent training adapts to industry and enterprise development.

\subsection{To Create Campus Production Training Base}

In order to overall train practical ability and business ability of cross-border e-commerce talents, $\mathrm{J}$ College should comprehensively integrate the resources of campus and off-campus business English training bases, effectively introduce cross-border leading enterprises, and create the campus production training base which takes vocational ability of cross-border e-commerce talents as the core and adapts to students' training, practice and entrepreneurship needs [5].

Firstly, the introduction of enterprise projects aims to achieve all-round innovation of practical teaching contents and means. In view of education and teaching idea of J College, the college and enterprises should jointly formulate practical teaching programme, rationally arrange practical training content in combination of enterprises' actual demands, implant enterprise projects in practical training and implement the project-centered project teaching mode. Meanwhile, full-time and part-time teachers should cooperate with each other to effectively combine theory teaching and practical teaching.

Secondly, "order class" should be set up to meet individualized talent training demand. Generally, cross-border e-commerce retail import and export enterprises are required to own sufficient cross-border platform operation personnel, promotion personnel and sales personnel. Through the application of "order class" teaching mode, enterprises' demand for talents can be matched. The most outstanding feature of "order class" is that the teaching content may be set by combining the special requirements of enterprises to make sure students' skill training adapts to enterprise post requirements, and the training objective keeps consistent with the enterprise employment standards. Through the application of "order class" teaching mode, students can adapt to and get used to internal changes of enterprises in advance so that their adaptive phase can be shortened in work.

Thirdly, the cross-border e-commerce operating center should be constructed, and agency operation service should be provided for enterprises. With the help of the opportunity that local medium and small foreign trade enterprises transit to cross-border e-commerce, it is required to actively build the cross-border e-commerce operating center, achieve cooperation between enterprises and teachers, guide students to make them offer necessary agency operation service for enterprises, make students' practical training own more real project and environment and make them accumulate richer practical experience for cross-border platform in practical environment.

Fourthly, entrepreneurship encouragement should be given for students to cultivate their entrepreneurship. With sustainable development of cross-border e-commerce platform C2C and B2C business, the good development opportunity is created for students' business startup. In such case, local regional resources should be utilized to guarantee enterprise cooperation and coordination, and provide multiple cross-border e-commerce platforms for students and entrepreneurial platforms. In this way, students can grasp vocational skills in entrepreneurial practice.

\section{Conclusions}

In conclusion, cross-border e-commerce is not a business mode. Its position and function far exceed business. Under the social background of informatization and marketization, cross-border e-commerce gradually develops to a key path for resource allocation and can effectively drive sustainable development of regional economy. The development of cross-border e-commerce also gradually becomes the foundation for cultivating cross-border e-commerce talents. Regional resource conditions of Hainan Province and school-running conditions of $\mathrm{J}$ College further facilitate the cultivation of cross-border e-commerce talents. The construction of cross-border e-commerce talent training mode can better adapt to regional economic development. 


\section{Acknowledgements}

Teaching reform research and scientific research project of colleges and universities in Hainan Province: Research on Cross-border E-commerce Talent Training for Regional Economic Development in Hainan Province, No.: Hnjg2016-58.

\section{References}

[1] Li Ying, Innovation research on cross-border e-commerce talent training strategy for vocational colleges in Henan, Juan Zong, 2017(27):112-112.

[2] Deng Zhichao, Application of cross-border e-commerce talent training mode in higher vocational schools based on production-education integration, China Business \& Trade, 2017(9):189-190.

[3] Tang Weiping, Exploration of cross-border e-commerce talent training in Xiamen, E-Business Journal, 2015(6):70-71.

[4] Tao Liping, Shen Houkun, Exploration on the path of cross-border e-commerce talent training for higher vocational colleges, Labor Security World, 2017(23):37, 39.

[5] Qian Linyi, Study on connection between cross-border e-commerce talent training norms and occupational ability requirements, Journal of Wuxi Institute of Commerce, 2017(5):97-101. 